\title{
A ESTAÇÃO PALEOLÍTICA DO CERRO (VILA NOVA DE GAIA, NOROESTE DE PORTUGAL): CARACTERIZAÇÃO PRELIMINAR DOS UTENSÍLIOS COM CONFIGURAÇÃO BIFACIAL
}

\author{
SÉrgio MonteIRO-RODRIGUES ${ }^{(1)} \&$ JoÃo PEDRO CUNHA-RIBEIRO ${ }^{(2)}$
}

Resumo:

\begin{abstract}
A estação paleolítica do Cerro foi descoberta em 1988. Entre 1989 e 1992 realizaram-se três campanhas de escavação que permitiram recolher um importante conjunto de artefactos líticos talhados a partir de seixos rolados de quartzito, atribuíveis ao Paleolítico Inferior. Do ponto de vista geoarqueológico, estes artefactos associam-se a coluviões, que se sobrepõem a uma formação marinha implantada a cerca de $22 \mathrm{~m}$ n.m.a.m. O estudo das peças com configuração bifacial (em que também se incluem as parcialmente bifaciais e as unifaciais) revelou a existência de duas cadeias operatórias, globalmente expeditas, que visaram, sobretudo, a criação de utensílios com extremidade distal apontada. Estas cadeias operatórias mais do que se ligarem a opções de natureza morfológica parecem antes constituir uma resposta aos constrangimentos impostos pela volumetria dos suportes utilizados, visando a sua eventual adequação a distintas funcionalidades.
\end{abstract}

Palavras-chave: Utensílios com configuração bifacial, Tecnologia lítica, Paleolítico Inferior, Noroeste de Portugal

\begin{abstract}
:
The Palaeolithic site of Cerro (Vila Nova de Gaia, NW Portugal): A preliminary analysis of the bifacial shaped tools

The Palaeolithic site of Cerro was discovered in 1988. Between 1989 and 1992 three excavation seasons were carried out, which allowed collecting an important set of macrolithic stone tools most of them made of quartzite pebbles, possibly dating from the Lower Palaeolithic. From a geoarchaeological point of view, these stone tools were associated with colluvial deposits which overlay a marine formation c. $22 \mathrm{~m}$ a.s.l. The study of the bifacial shaped tools (including the parcial bifacial shaped and the unifacial tools) allowed the identification of two chaines operatoires, basically expedite, oriented towards the production of pointed tools These chaines operatoires do not seem to be linked to morphological options but instead they may be a response to the constraints imposed by the volumetry of the blanks, possibly adapting them to distinct funcionalities.
\end{abstract}

Keywords: Bifacial shaped tools, Lithic technology, Lower Palaeolithic, Norwestern Portugal

\section{INTRODUÇÃO}

A estação paleolítica do Cerro - freguesia da Madalena, concelho de Vila Nova de Gaia, distrito do Porto (Fig. 1) - foi descoberta em 1988, na sequência de prospecções arqueológicas levadas a cabo ao longo da faixa litoral do referido concelho. Entre 1989 e 1992 realizaram-se três campanhas de escavação que permitiram reconhecer a importância da jazida (MONTEIRORODRIGUES \& CUNHA-RIBEIRO 1991; MONTEIRO -RODRIGUES \& SANCHES 2006). No entanto, sucessivos compromissos de investigação noutras regiões do País impediram a continuidade dos trabalhos, ficando por fazer o estudo detalhado da colecção lítica exumada, bem como outras acções de campo no sentido de melhor a contextualizar do ponto de vista cronoestratigráfico. Em todo o caso, o potencial arqueológico da estação do Cerro nunca foi descurado, pelo que se preten- de criar condições para reiniciar a investigação no local, desta vez num quadro de colaboração interdisciplinar.

O texto que agora se apresenta procura marcar, precisamente, o reinício desta investigação, abordando, por um lado, alguns problemas de natureza geoarqueológica inerentes à jazida do Cerro e, por outro, aspectos tecnológicos relativos aos denominados utensílios com configuração bifacial.

O estudo específico destes utensílios, e não da indústria lítica no seu conjunto, resultou de uma opção dos autores, que consideram que as particularidades tecnológicas destas peças e a sua representatividade na colecção constituída merecem uma atenção particular. Em todo o caso, esta abordagem não deixará de ser posteriormente desenvolvida e incorporada na análise global do conjunto lítico da estação arqueológica do Cerro.

\footnotetext{
(1) Universidade do Porto. Faculdade de Letras, DCTP. Centro de Estudos de Arqueologia, Arte e Ciências do Património. sergiomonteirorodrigues@gmail.com

${ }^{(2)}$ Universidade de Lisboa. Faculdade de Letras. UNIARQ. jppgcr@gmail.com
} 


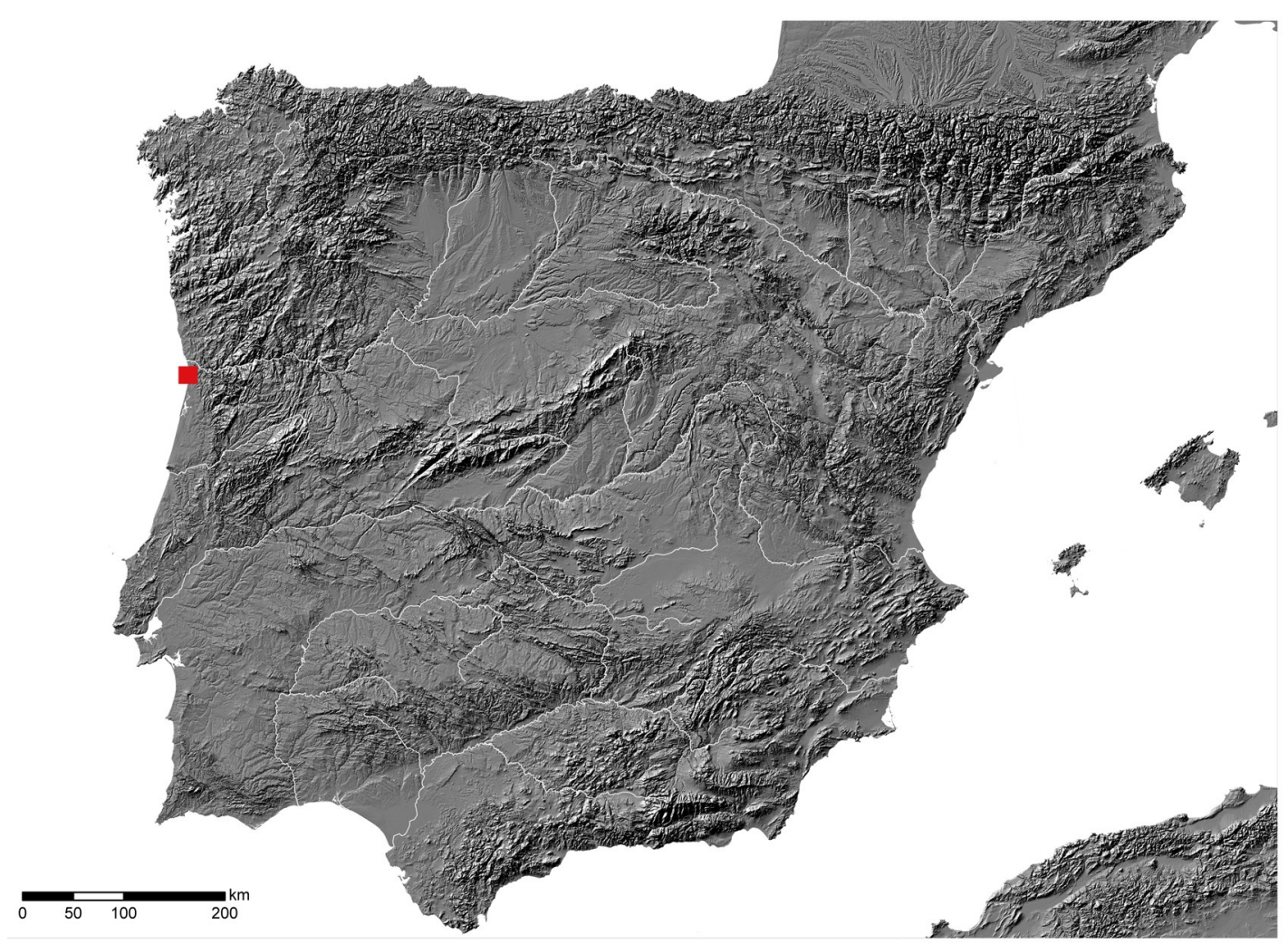

Fig. 1. Localização da estação paleolítica do Cerro na Península Ibérica. Coordenadas geográficas do sítio: 41 06 ' $32,35^{\text {' }} \mathrm{N}$ 839'08,96''W Greenwich.

Fig. 1. Location of the Palaeolithic site of Cerro in the Iberian Peninsula. Geographic coordinates of the site: $41^{\circ} 06$ ' $32,35^{\prime \prime} \mathrm{N}$ 839'08,96'W Greenwich.

\section{CONTEXTO GEOARQUEOLÓGICO}

As escavações arqueológicas realizadas na jazida do Cerro permitiram identificar um depósito com uma espessura superior a $2 \mathrm{~m}$, definido por seis unidades estratigráficas (Fig. 2A). Estas unidades podem agrupar-se em dois conjuntos em função da sua sedimentogénese. O conjunto inferior, integrando as unidades estratigráficas $\mathrm{C} 6$ e $\mathrm{C}^{1}$, corresponde a um depósito marinho, constituído por uma unidade basal cascalhenta (C6) e por uma unidade superior arenosa (C5) (Fig. 3). A unidade C6, com uma espessura que varia entre $1 \mathrm{~m}$ e 50 $\mathrm{cm}$, é formada por seixos rolados achatados, embalados numa matriz arenosa grosseira com coloração amarelada. Apesar de globalmente pouco consolidada, observaram-se zonas concrecionadas por óxidos de ferro, sobretudo na base do depósito. A unidade C5 é constituída exclusivamente por areia fina, não concrecionada, evidenciando igualmente tonalidade amarelada; a sua espessura varia entre 20 e $70 \mathrm{~cm}$. Estas duas unidades apresentam estratificação horizontal.

O conjunto superior, de fácies continental, integra um depósito coluvionar (C4), um depósito de génese ainda indeterminada (C3), uma casca- lheira clasto suportada, sem matriz (C2), e o "solo" actual (C1) (Figs. 2A e 3). Entre estas diversas unidades observam-se descontinuidades, com prováveis truncamentos erosivos.

A coluvião $\mathrm{C} 4$ é composta por sedimento areno-siltoso, maciço, de cor castanha avermelha$\mathrm{da}$, que embala seixos rolados heterométricos e artefactos líticos talhados, apresentando uma espessura que varia entre os 0 e os $60 \mathrm{~cm}$.

A unidade estratigráfica $\mathrm{C} 3$, inicialmente atribuída de forma genérica a processos de coluvionamento, é formada por material muito fino, essencialmente silte com alguma areia, sugerindo ambientes de tipo lagunar ou de intenso transporte eólico (ZBYSZEWSKI 1943; ARAÚJO 1995; RIBEIRO et al. 2010). ZBYSZEWSKI (1943) utiliza a expressão "limon loéssico" para descrever este depósito. Em certos perfis da escavação, e a afectar a unidade estratigráfica $\mathrm{C} 3$, observaram-se stone-lines muito delgadas definidas por seixos rolados de pequenas dimensões, aparentemente com origem nas cascalheiras da área do Cerro. Estas stone-lines poderão corresponder a paleo-superfícies ou a pequenos paleocanais que trucam o depósito, testemunhando, possivelmente, modificações ambien-

${ }^{1}$ Na publicação de 1991 (Monteiro-Rodrigues \& Cunha-Ribeiro 1991) esta unidade estratigráfica foi interpretada como resquício de cobertura dunar antiga. Contudo, o posterior acesso a outros perfis estratigráficos da área em torno do Cerro permitiu reformular tal interpretação. 
A Estação Paleolítica do Cerro (Vila Nova de Gaia, Noroeste de Portugal): Caracterização preliminar dos utensílios com configuração bifacial

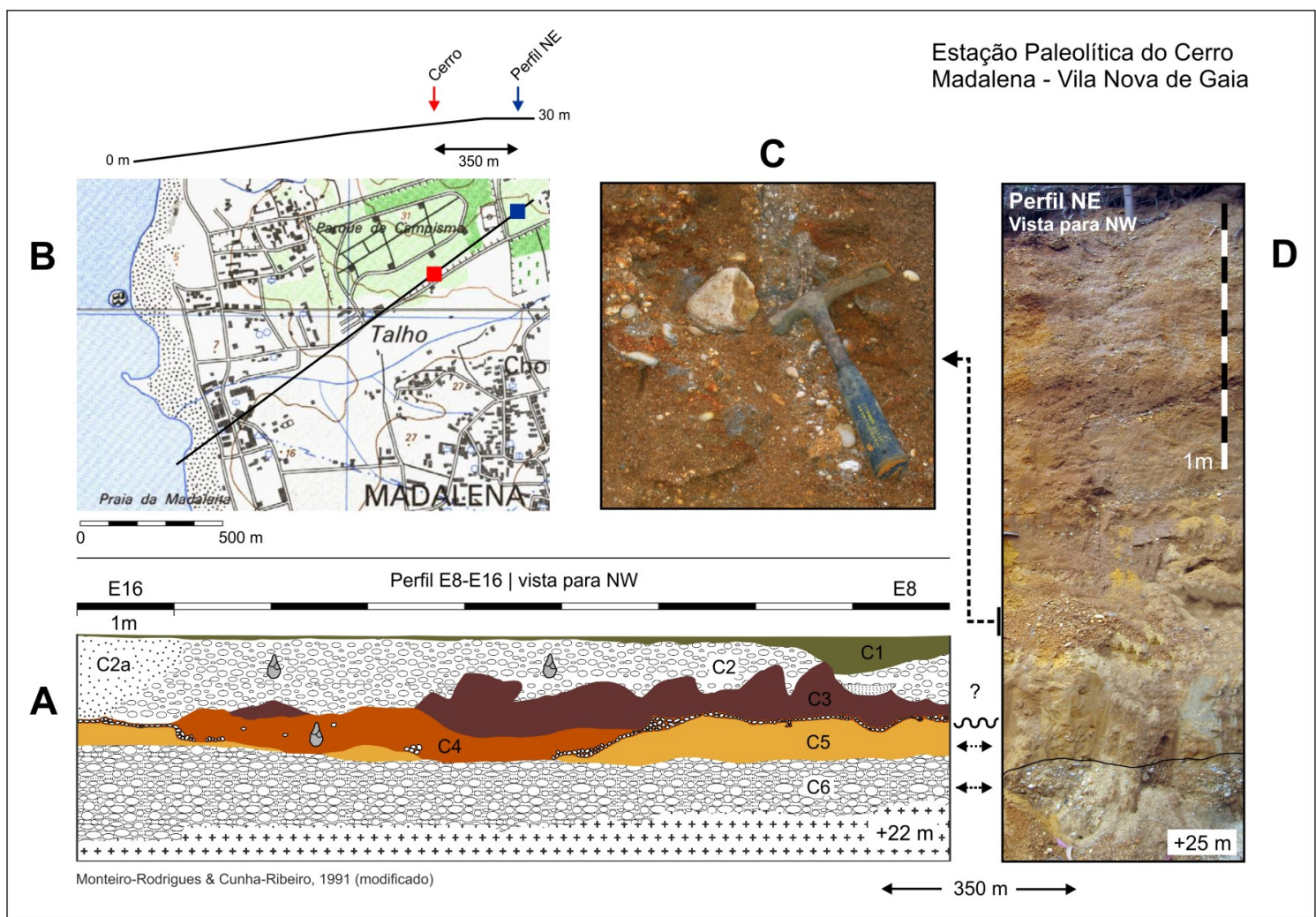

Fig. 2. A: Perfil estratigráfico E8-E16. B: Perfil topográfico, localização do sítio do Cerro e localização do perfil NE em extractos da Carta Militar de Portugal na escala 1/25000, folhas 122 (Porto) e 133 (Valadares). C: Seixo talhado unifacial in situ no depósito marinho do perfil NE. D: Perfil NE: Depósito marinho.

Fig. 2. A: Drawing of the cross-section E8-E16. B: Topographic profile and the location of the Palaeolithic site of Cerro and the NE crosssection in Carta Militar de Portugal, 1/25000 scale, sheets 122 (Porto) and 133 (Valadares). C: Chopper in situ in the marine formation of NE cross-section. D: NE cross-section: marine formation.

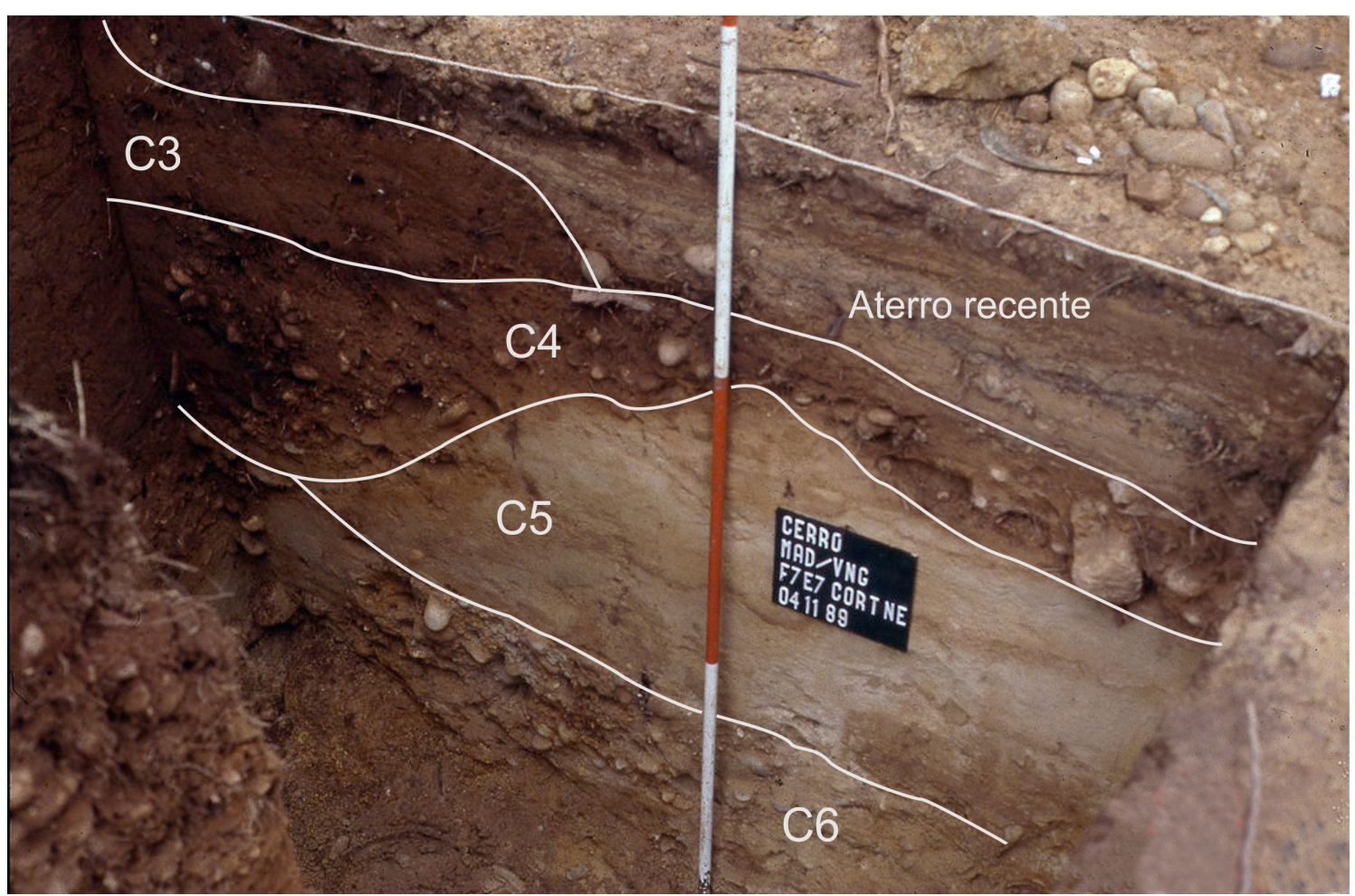

Fig. 3. Perfil estratigráfico do Cerro. Unidades C6 e C5: depósito marinho; Unidade C4: depósito coluvionar; Unidade C3: depósito indeterminado.

Fig. 3. Cerro's cross-section. Units C6 and C5: marine deposits; Unit C4: colluvial deposit; Unit C3: undetermined deposit. 
tais com reflexo nos processos sedimentares. A unidade C3 apresenta coloração castanha escura e uma espessura que varia entre 10 e $70 \mathrm{~cm}$.

A unidade $\mathrm{C} 2$ consiste numa cascalheira formada exclusivamente por clastos rolados que preenchem diversos leitos encaixados na unidade C3. A inexistência de organização e de imbricamento dos clastos, o seu carácter heterométrico e, como se referiu, a ausência de matriz parecem documentar um mecanismo do tipo fluxo de detritos (debris flow) mais ou menos canalizado, que retoma material sedimentar de depósitos mais antigos, nomeadamente artefactos líticos acheulenses. Estes artefactos evidenciam um boleamento significativo, ao contrário do que sucede na unidade $\mathrm{C} 4$.

$\mathrm{O}$ substrato granítico, profundamente alterado e com zonas deprimidas que poderão corresponder a "marmitas", define uma superfície irregular, testemunho de uma antiga plataforma de abrasão marinha. As referidas depressões e a própria irregularidade da superfície contribuíram para a conservação localizada dos depósitos quaternários.

Em 2007, a construção de um edifício a aproximadamente $350 \mathrm{~m}$ a nordeste da estação do Cerro pôs a descoberto um depósito marinho com mais de $2,5 \mathrm{~m}$ de espessura, formado, genericamente, pela alternância de níveis cascalhentos e níveis arenosos finos - denominado perfil NE (Fig. 2D). A semelhança entre os níveis inferiores deste depósito e os inferiores do sítio do Cerro (unidades C6 e C5) permite, eventualmente, correlacioná-los, pelo que ambos poderão pertencer à mesma formação marinha, implantada a c. 22-35 m n.m.a.m (cotas relativas à base do depósito) (e.g. ARAúJO 1991, 1997, 2008). No entanto, na área da estação arqueológica, os processos erosivos/ coluvionamento terão truncado a sequência marinha original. Tal facto justifica, certamente, a existência de apenas duas unidades marinhas no perfil estratigráfico do Cerro, o que não sucede no depósito a nordeste.

Neste mesmo depósito - mais precisamente num nível cascalhento intermédio - identificou-se um seixo talhado unifacial in situ ${ }^{2}$, ligeiramente boleado, embalado numa matriz arenosa avermelhada, bastante concrecionada (Figs. 2C e 4). Para já não é possível estabelecer qualquer relação entre este artefacto e os materiais líticos da jazida do Cerro. Todavia, esta ocorrência permite levantar a hipótese de pelo menos algum do material lítico do Cerro poder ser correlativo daquele nível marinho, encontrando-se actualmente em posição secundária em consequência de processos de coluvionamento. Trata-se de um aspecto a tentar esclarecer em investigação futura.

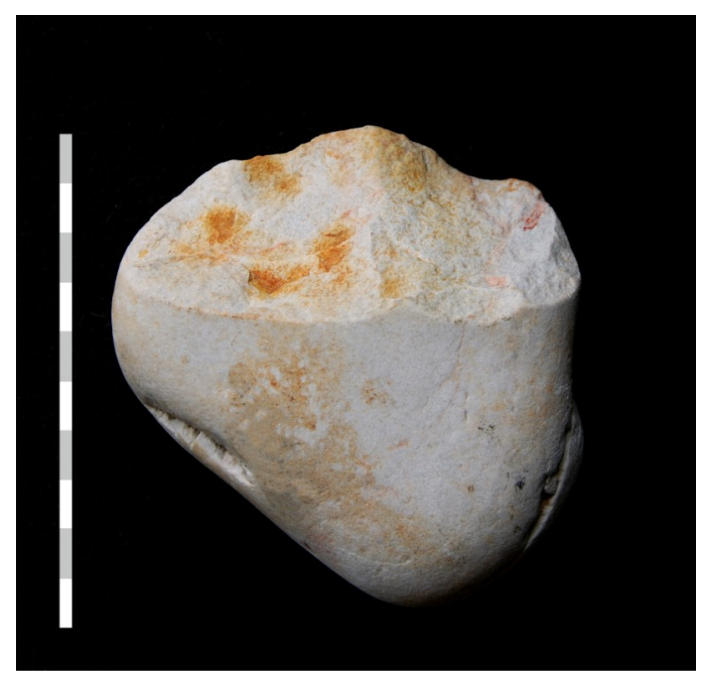

Fig. 4. Seixo talhado unifacial identificado no depósito marinho do perfil NE.

Fig. 4. Chopper collected in the marine formation of NE crosssection.

Relativamente à cronologia das formações sedimentares, não existem ainda dados que permitam estabelecer a sua idade absoluta. De acordo com diversos estudos sobre a plataforma litoral da região do Porto, o nível marinho atribuído ao Eemiano poderá estar, em alguns sectores, implantado à cota aproximada de $1 \mathrm{~m}$ n.m.a.m (e.g. ARAÚJO 2008; ARAÚJO et al. 2003; MONTEIRORODRIGUES \& GONZÁLEZ 2010). Tendo em conta que as praias elevadas da região se desenvolvem em "escadaria" e que o depósito marinho do Cerro atinge uma altitude superior a $20 \mathrm{~m}$ n.m.a.m., ter-se -á de considerar que a sua idade será necessariamente anterior ao último período interglaciar.

Actualmente dispõe-se de uma datação de $180 \pm 25 \mathrm{Ka}$, obtida por OSL sobre quartzo, para um terraço marinho implantado a cerca de $15-18 \mathrm{~m}$ n.m.a.m - terraço da praia de Pedras Amarelas, Lavadores, Vila Nova de Gaia (RIBEIRO et al. 2010; ARAÚJO 2008). Muito embora este valor cronométrico possa estar aquém da idade real do depósito devido às limitações inerentes à datação do quartzo (CUNHA et al. 2008; MARTINS et al. 2009) -, ele permite aceitar a possibilidade da formação marinha do Cerro datar, no mínimo, do MIS 7.

No que diz respeito à coluvião representada pela unidade estratigráfica $\mathrm{C} 4$, a presença de bifaces e de machados de mão com arestas vivas e sem qualquer evidência de rolamento poderá remeter a sua génese para um âmbito cronológico genericamente coincidente com o Acheulense. No entanto, como foi referido, nada impede que estes artefactos

${ }^{2}$ Até 2007, e excluindo as descobertas da Praia da Aguda (Monteiro-Rodrigues \& Gonzalez 2010), nunca tinha sido detectado no litoral de Vila Nova de Gaia qualquer atefcto litico lascado inequivocame nho, mas este implanta-se a apenas $1 \mathrm{~m}$ n.m.a.m. 
se relacionem com outros depósitos mais antigos, pelo que, neste caso, poderia haver um intervalo temporal alargado entre a idade da indústria lítica e a deposição da unidade $\mathrm{C} 4$. Aceitando, ainda que a título de hipótese, a correspondência entre as unidades $\mathrm{C} 4 / \mathrm{C} 3$ e o depósito da "Formação Arenopelítica de Cobertura" de Lavadores (COSTA \& TEIXEIRA 1957; TEIXEIRA \& PERDIGÃO 1962; ARAÚJO 1984, 1991, 1995; RIBEIRO et al. 2010), estar-se-ia perante contextos sedimentares com uma idade em torno de 40-45Ka BP $\left({ }^{14} \mathrm{C}\right.$ ) (ARAÚJO 199533 RIBEIRO et al. 2010). Importa sublinhar, no entanto, que a referida formação de cobertura tem um carácter policíclico (ARAÚJO 1984, 1991, 1995), pelo que esta datação poderá dizer respeito a apenas uma das múltiplas fases em que se reuniram condições ambientais favoráveis à sua génese.

Relativamente à unidade $\mathrm{C} 2$, não é para já possível tecer qualquer consideração sobre a sua idade.

\section{OS UTENSÍLIOS COM CONFIGURAÇÃO BIFACIAL, BIFACIAL PARCIAL E UNIFA- CIAL}

Entre os materiais líticos talhados recolhidos na jazida paleolítica do Cerro no decurso das prospecções e das escavações arqueológicas destacamse, pelo seu expressivo número, os utensílios com configuração bifacial, bifacial parcial e unifacial. Num conjunto de mais de três centenas de peças, estes utensílios agrupam 118 artefactos, que em termos formais e de acordo com as suas características morfo-tipológicas, poderiam associar-se aos bifaces, bifaces parciais, esboços de bifaces ou unifaces. No entanto, o facto de a sua volumetria final se traduzir na prática na justaposição de duas faces definidas de forma variável por talhe bifacial ou apenas unifacial levou a agrupá-los sobre a designação genérica de peças bifaciais.

À excepção de uma peça confeccionada num suporte indeterminado de corneana, e de três outras definidas por amplo talhe bifacial a partir de três aparentes lascas de quartzo, os restantes 114 artefactos considerados resultaram do aproveitamento claramente preferencial e maioritário do quartzito como matéria-prima $(96,6 \%)$. Mais de metade evidencia arestas relativamente bem preservadas $(55,1 \%)$, apresentando boa parte dos restantes artefactos arestas moderadamente boleadas (41,5\%) e limitando-se os materiais muito alterados por boleamento a apenas quatro casos $(3,4 \%)$.

Dos 118 artefactos estudados $50 \%$ testemunha, por sua vez, a escolha de seixos rolados de quartzito como suporte, seguindo-se a relativa distância o recurso a calotes de seixo e a lascas (representando ambos os casos 15,3\%). Note-se que a escassez das lascas não pode ser dissociada da circunstância de a dimensão dos seixos rolados de quartzito localmente disponíveis não permitir a obtenção de suportes com dimensões adequadas. Num único caso registou-se ainda o aproveitamento de uma plaqueta de quartzito $(0,8 \%)$, revelandose nas restantes peças impossível determinar o tipo de suporte usado $(18,6 \%)$.

Trata-se, em geral, de peças com uma morfologia claramente apontada e, na maior parte dos casos, com base espessa, quase sempre cortical. Uma percentagem esmagadora dos artefactos apresenta, com efeito, extremidade distal apontada em resultado da convergência dos seus dois bordos laterais $(91,5 \%)$, independentemente da extensão do talhe que a define ou da incidência uni ou bifacial deste. Numa parte significativa destas peças a morfologia da ponta surge frequentemente arredondada $(23,9 \%)$, quase sempre com recurso a retoque. Situação similar poderia, aliás, ocorrer também entre as peças cuja parte distal ou apenas a extremidade se apresenta eliminada por fractura (29,1\%). Em contraponto, só um reduzido conjunto de artefactos está associado a uma morfologia arredondada da extremidade distal na continuidade clara da silhueta dos bordos adjacentes da peça $(6 \%)$.

Já no que se refere à extremidade proximal, prevalecem entre estes materiais as bases espessas corticais $(71,8 \%)$, resultantes da conservação local da morfologia original do suporte. Das restantes peças, algumas apresentam também bases espessas, embora parcialmente corticais em virtude da incidência pontual de talhe unifacial $(13,7 \%)$. Só numa dúzia de peças foi possível assinalar a existência de arestas cortantes na zona proximal, determinadas pela incidência de talhe uni e bifacial $(10,2 \%)$.

Do ponto de vista da definição volumétrica, estes artefactos estão longe de evidenciar um apurado equilíbrio. No que se refere ao equilíbrio bilateral das respectivas silhuetas é manifesto o predomínio de peças com uma clara assimetria entre os dois bordos que as delimitam (48,7\%), seguindo-se de muito perto o número das que apresentam uma silhueta simétrica bastante irregular (41\%), e apenas uma dezena de peças surge com uma silhueta bem mais equilibrada $(8,5 \%)$. Situação similar observa-se quando se avalia também o seu equilíbrio bifacial, já que é evidente o predomínio dos utensilios com secção longitudinal biconvexaassimétrica $(44,2 \%)$, seguindo-se pela ordem da sua representação numérica os que evidenciam uma secção plano-convexa (23\%) e tabular $(18,6 \%)$. Raros são assim os artefactos que apresentam secção biconvexa-simétrica $(5,3 \%)$, situação em boa parte determinada pela preservação da

${ }^{3} \mathrm{O}$ valor radiométrico publicado pela autora, relativo a um corte de Lavadores, é de 44.370 BP. Uma vez que ele se encontra próximo do limite cronológico definido pelo método do radiocarbono há que considerar a possibilidade do depósito ser mais antigo. 
nem sempre muito regular morfologia original dos suportes utilizados e pelo desenvolvimento de um processo de configuração as mais das vezes sumário, em que a definição dos atributos que os caracterizam é frequentemente reduzido ao mínimo indispensável.

A análise do sistema de produção destas peças permitiu identificar a presença de sete sequências de talhe distintas, por vezes com variantes bem definidas no seu interior (Fig. 5), visando todas elas a obtenção de peças com uma configuração volumétrica resultante da intersecção de duas faces justapostas, definidas por talhe bifacial, parcialmente bifacial ou mesmo unifacial.

Uma primeira, que designámos como sequência de talhe 0, agrupa um pequeno conjunto de cinco peças que evidenciam um judicioso aproveitamento da morfologia original dos suportes seleccionados, boa parte dos quais correspondentes a lascas de quartzito. O seu expedito processo de configuração limita-se à extracção de um reduzido número de levantamentos, quase sempre destinados a definir uma extremidade distal apontada ou a reforçar a morfologia naturalmente afilada do suporte utilizado.

Numa das peças associadas a esta sequência de talhe (Fig. 6a), definida a partir de uma ampla e espessa lasca de quartzito de talão liso, é bem clara a intenção que houve de aproveitar a morfologia criada pela preservação, ao longo do bordo esquerdo, de uma ampla placa cortical em posição oblíqua, na definição de uma extremidade distal apontada. A configuração do artefacto restringiu-se ao afeiçoamento sumário do bordo direito visando, para a prossecução do objectivo referido, a criação de um diedro convergente com o plano constituído pela face inferior do suporte, processo esse complementado pela pontual regularização dos gumes de ambos os bordos, na face oposta.

Bem melhor estruturada, ainda que também marcadamente expedita, a sequência de talhe 1 (Fig. 5) reúne um conjunto de 15 artefactos cuja configuração se iniciou com a obtenção de um primeiro e único levantamento no anverso da peça. Trata-se de um levantamento em geral com uma amplitude marginal e inclinação oblíqua, desenvolvendo-se o respectivo negativo preferencialmente na metade distal do bordo em que incide. Utilizando-o como plano de percussão, inicia-se, em seguida, o talhe do reverso, o qual é posteriormente complementado pela extracção de um ou mais levantamentos a partir do bordo oposto desta face, resultando da convergência dos dois bordos assim definidos uma extremidade cujo destaque é frequentemente realçado pela concavidade de um ou mesmo dos dois referidos bordos.

Este desenvolvimento sequencial do talhe das duas faces é por vezes substituído por uma estratégia parcialmente alterna, com o talhe do reverso a iniciar-se com a extracção de levantamentos a partir do bordo oposto àquele em que incidiu o levantamento prévio no anverso, para só em seguida se utilizar o negativo deste último levantamento como plano de percussão para a obtenção dos levantamentos convergentes (novamente no reverso), que vão determinar a configuração da extremidade distal da peça. Correspondendo esta opção a uma variante da primeira, foi possível distingui-la designando-a sequência de talhe $1 \mathrm{~b}$, por oposição à originalmente identificada, denominada sequência de talhe 1a (Fig. 5). Em qualquer dos casos, porém, é manifesta a intenção de criar um artefacto com uma extremidade distal apontada, frequentemente destacada na silhueta da peça em função do perfil côncavo dos bordos talhados que a definem, apresentando-se, sempre que se encontra preservada, tendencialmente adelgaçada em relação à espessura da peça e arredondada por retoque (Figs. 6b e 7a).

Da aplicação desta sequência de talhe, nas suas duas versões, resulta a produção de bifaces parciais, quase sempre espessos, muitas das vezes próximos dos unifaces, com uma silhueta frequentemente langeniforme, conservando em geral na sua zona proximal a morfologia original dos suportes utilizados. O levantamento inicial que incide no anverso do artefacto surge claramente como um elemento facilitador do talhe subsequente, que se desenvolve na face oposta, não deixando ao mesmo tempo de contribuir também para delinear a morfologia côncava do bordo em que se inscreve. Tudo isto independentemente do tipo de suporte utilizado, da sua diversificada espessura ou da sua maior ou menor irregularidade, sendo porém bem expressiva, em qualquer dos casos, a utilização de seixos rolados e, em menor número, de calotes de seixos.

A sequência de talhe 2, reunindo um conjunto de oito artefactos, traduz-se numa configuração bifacial claramente mais marcada das peças envolvidas, e embora corresponda, em certa medida, a um desenvolvimento do processo de produção delineado na sequência de talhe anterior, está longe de constituir uma simples evolução do mesmo (Figs. 5, 6c e 7b).

A sequência de talhe 2 basicamente compartilha com a 1 a circunstância de o processo de configuração bifacial dos seus artefactos se iniciar também pela obtenção de um primeiro levantamento num dos bordos laterais de uma das faces do artefacto. Mas se é a partir dele que se desenvolve em parte $o$ talhe da face oposta, esta segunda fase do processo de configuração das peças não visa agora a criação de uma morfologia apontada, mas tão-só a criação de uma ampla face definida por talhe invasor, a partir da qual se acaba por completar, posteriormente, o talhe da primeira face intervencionada.

O agenciamento do talhe desta última face permite, aliás, individualizar também aqui duas distintas ver- 
A Estação Paleolítica do Cerro (Vila Nova de Gaia, Noroeste de Portugal):

Caracterização preliminar dos utensílios com configuração bifacial

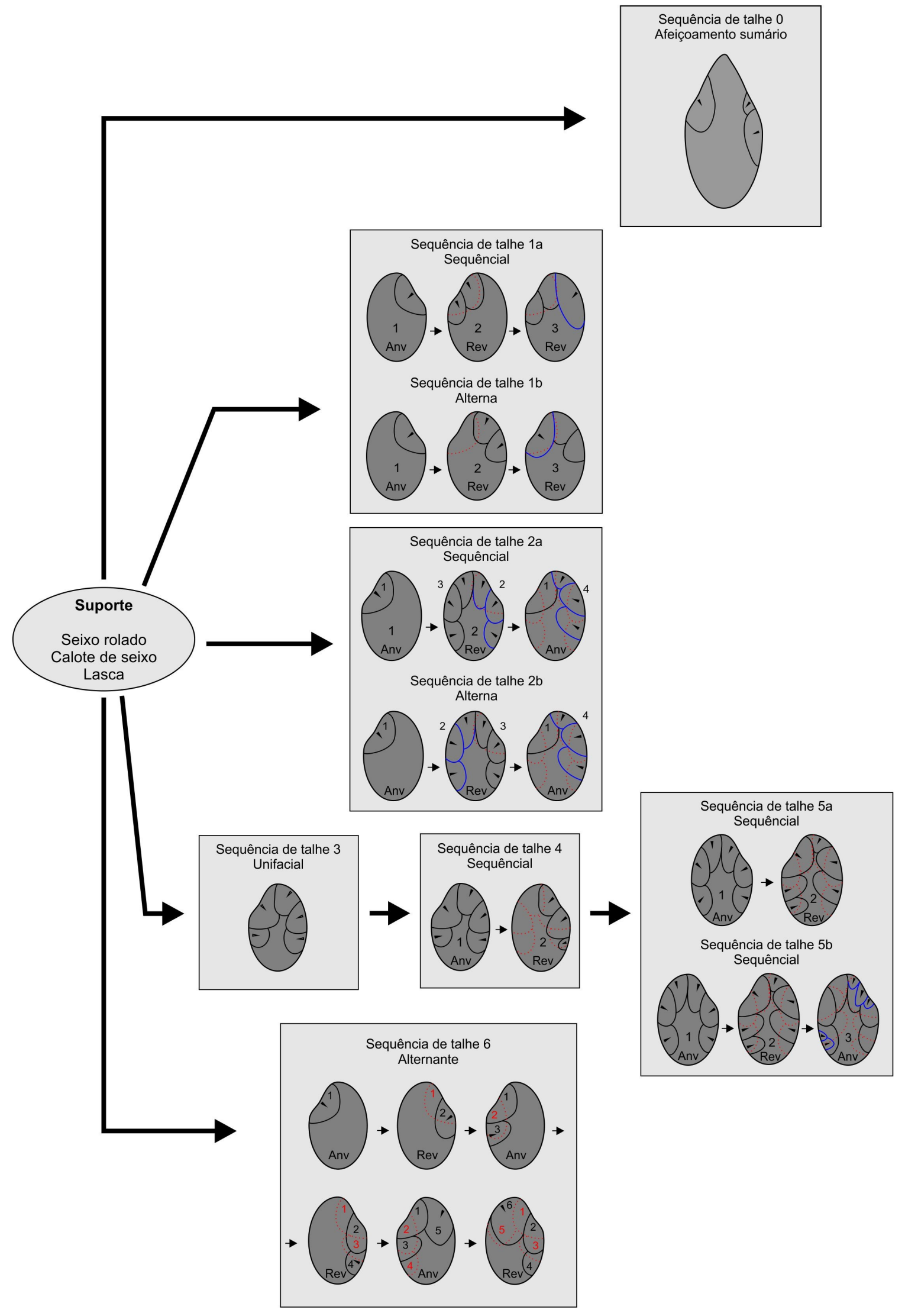

Sequência de talhe 0 Afeiçoamento sumário

Fig. 5. Sequências de talhe de produção de utensílios com configuração bifacial (I). Fig. 5. Shaping sequences for production of bifacial shaped tools (I). 


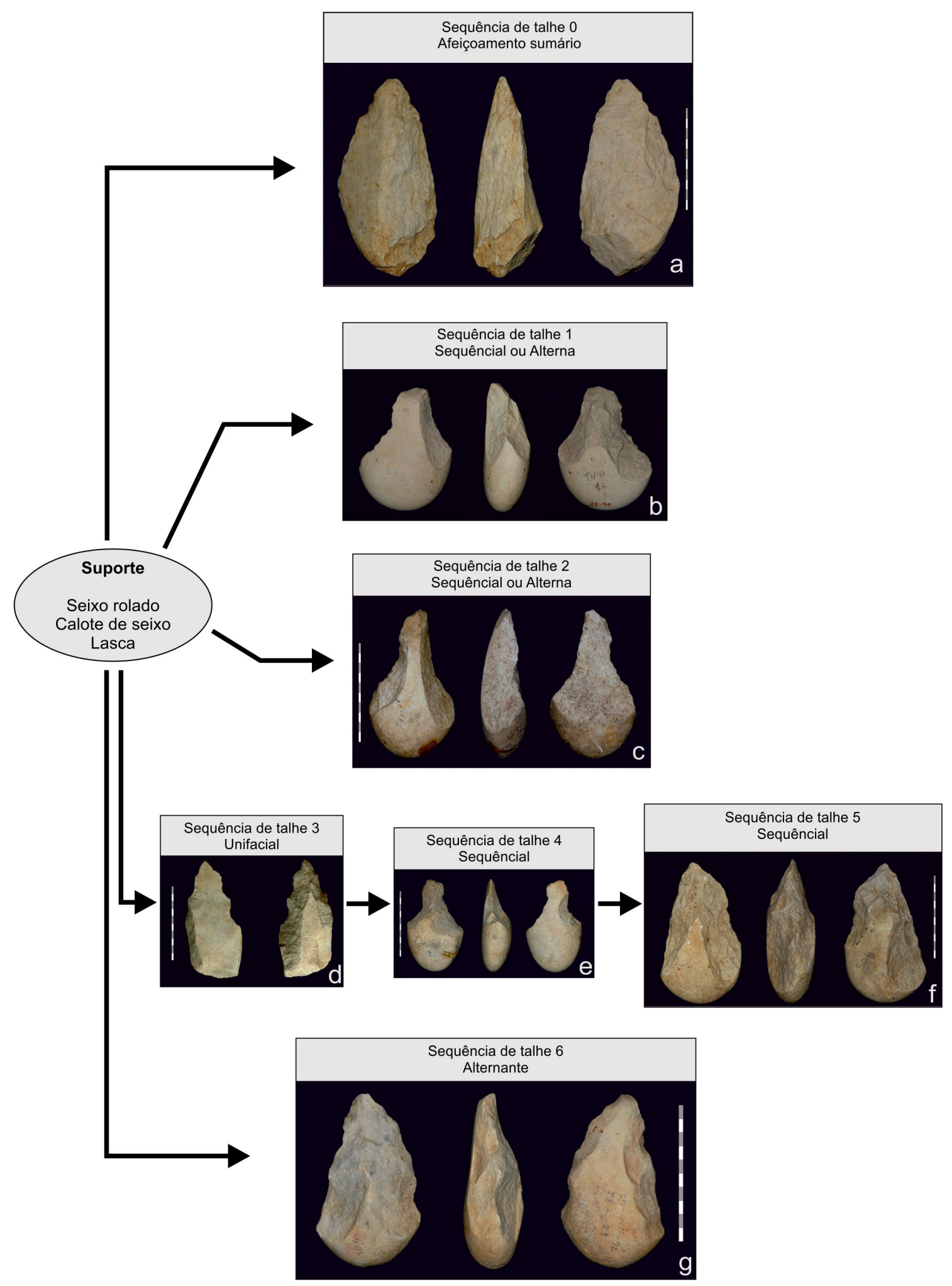

Fig. 6. Sequências de talhe de produção de utensílios com configuração bifacial (II).

Fig. 6. Shaping sequences for production of bifacial shaped tools (II). 

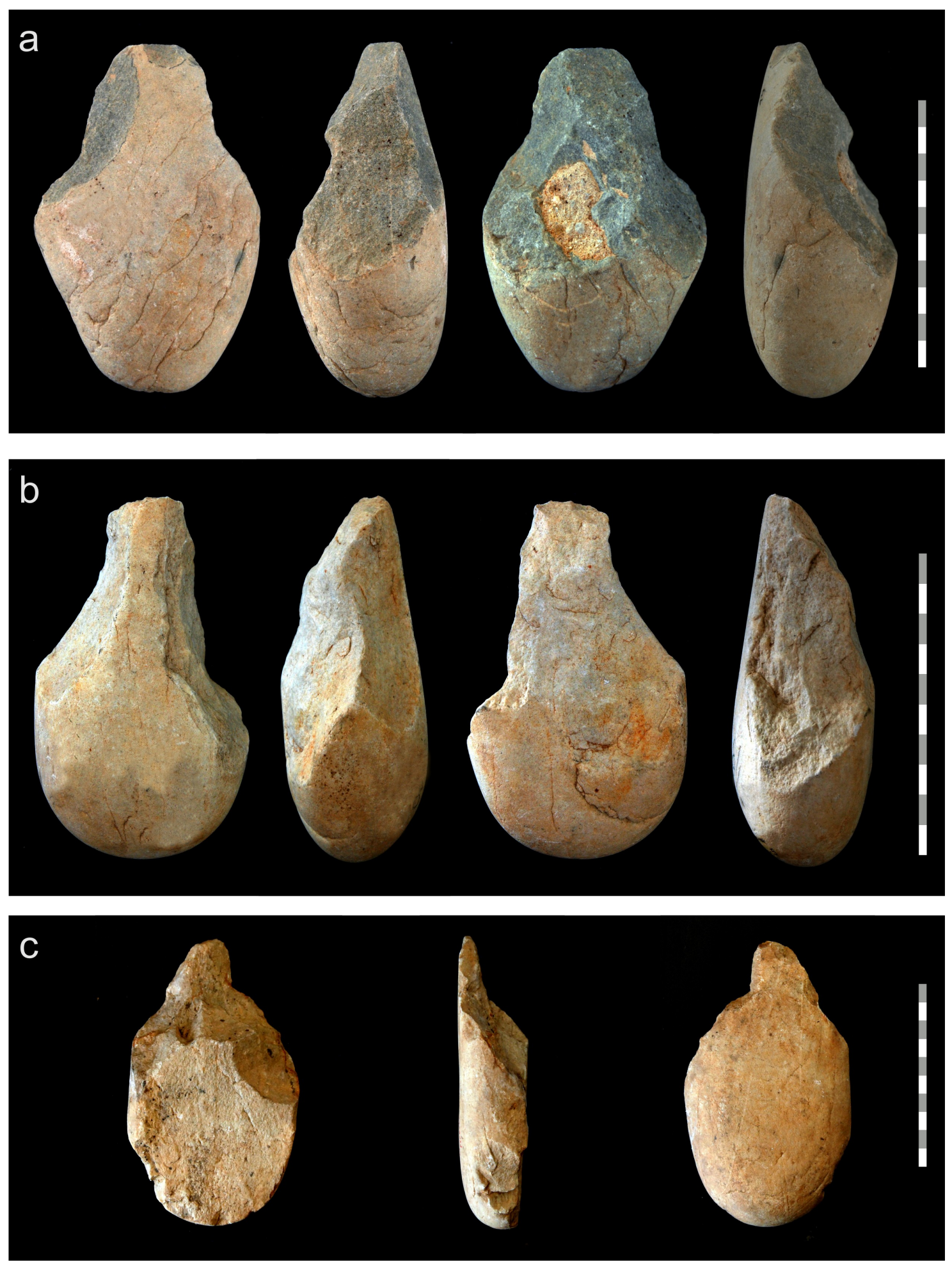

Fig. 7. Utensílios com configuração bifacial (I). a: Sequência de talhe 1; b: Sequência de talhe 2; c: Sequência de talhe 3.

Fig. 7. Bifacial shaped tools (I). a: Shaping sequence 1; b: Shaping sequence 2; c: Shaping sequence 3 .

sões desta mesma sequência de talhe. Na primeira versão, designada como sequência de talhe $2 \mathrm{a}$, o desenvolvimento do talhe na segunda face inicia-se pelo bordo a partir do qual se procedeu anteriormente à extracção de um primeiro levantamento na face oposta, utilizando o respectivo negativo como plano de percussão. Só em seguida se passa ao talhe desta segunda face a partir do bordo oposto, para terminar a operação com a retoma do talhe da face inicial, a partir deste último bordo, num processo de desenvolvimento claramente sequencial de 
configuração da peça. Na versão alternativa desta sequência de talhe, identificada como sequência de talhe $2 b, o$ talhe da segunda face da peça inicia-se pelo bordo oposto àquele onde se localiza o levantamento original, obtido na primeira face, delineando-se assim o desenvolvimento alterno da configuração bifacial do artefacto (Fig. 5). Em qualquer das situações, o levantamento original no anverso da peça surge também não apenas para facilitar o desenvolvimento subsequente do talhe da face oposta, como reforça igualmente a concavidade de um dos bordos, contribuindo para destacar a extremidade distal da peça.

A última fase de afeiçoamento, em qualquer das duas versões desta sequência de talhe, incide de novo na face por onde começou o talhe do artefacto. Os levantamentos marcadamente marginais e oblíquos que agora se efectuam contrapõem-se, no bordo oposto, ao negativo da extracção inicial, conservando-se por vezes centralmente uma placa cortical, que se estende até à extremidade distal da peça (Figs. 6c e 7b).

Mas se o resultado desta sequência de talhe se traduz, tal como na sequência de talhe 1 , na obtenção de peças com uma morfologia apontada - em que o destaque da extremidade distal é ainda muitas vezes realçado pelo perfil côncavo dos bordos adjacentes e com uma região proximal em que se conserva incólume o carácter espesso e cortical do suporte original, certo é que ela evidencia um desenvolvimento significativo da configuração bifacial. De facto, não apenas a extensão dos bordos definidos por talhe bifacial é bem maior, como também a sua incidência na face inferior da peça é em geral mais ampla, deixando entrever uma alteração mais significativa da morfologia original dos suportes e a produção de artefactos menos espessos.

Sendo a primeira asserção inquestionável, a segunda, porém, pode relacionar-se com a selecção de suportes mais adelgaçados, aparentemente melhor adequados para o desenvolvimento desta sequência de talhe. Desta mesma característica dos suportes resultaria ainda a opção pela definição da morfologia apontada das extremidades distais através da criação de bordos convergentes, por intermédio dos levantamentos marginais e marcadamente oblíquos na face superior das peças. Acresce que à semelhança do verificado com a sequência de talhe 1 , também aqui algumas das extremidades apontadas das peças, mesmo quando se encontram eliminadas por fractura, parecem ter sido arredondadas por retoque, embora a sua configuração não permita o adelgaçamento já anteriormente registado nalgumas situações e não se possa deixar de considerar em certos casos o seu efectivo afilamento.

A sequência de talhe 3 agrupa um conjunto diversificado de 27 peças com morfologia apontada e, em geral, base cortical espessa, decorrente de um processo de configuração exclusivamente unifacial (Figs. 5, 6d, 7c e 8a). Trata-se maioritariamente de utensílios resultantes da transformação de seixos rolados ou, em menor número, de calotes de seixo, que permite o aproveitamento pontual de suportes menos espessos, possibilitando, nomeadamente no caso dos últimos suportes considerados, a produção de peças unifaciais que se podem considerar formalmente planas $(\mathrm{m} / \mathrm{e}>2,23)$.

Os artefactos assim produzidos procuram no essencial mimetizar os estereótipos morfológicos obtidos com o desenvolvimento das cadeias operatórios 1 e 2, nas suas duas versões, definindo-se agora os seus principais atributos com recurso exclusivo ao talhe unifacial. A maior parte das peças deste conjunto (dezanove em vinte e sete) visa a criação de uma extremidade distal bem destacada, resultante da convergência de dois bordos em geral côncavos, definidos por talhe tendencialmente invasor. Esta situação permite adelgaçar a ponta que, quando não se encontra fracturada, evidencia uma morfologia cuidadosamente arredondada por retoque (Figs. 7c e 8a). Das restantes peças integradas nesta sequência de talhe unifacial, cinco evidenciam extremidade distal claramente afilada, resultante da intersecção do plano diédrico definido por talhe transversal, no anverso, com o plano original do suporte, conservado no reverso (Figs. 7c e 8a). Na prática corresponde ao desenvolvimento de uma estratégia que embora assente num agenciamento tecnologicamente distinto do ocorrido na sequência de talhe 2 , deixa transparecer certas semelhanças com soluções aí encontradas para a definição da morfologia apontada de algumas extremidades distais, muito embora agora, na sequência de talhe 3 , a amplitude do talhe envolvido no processo de configuração se revele bem mais ampla. Duas outras peças unifaciais mostram ainda uma clara similitude com alguns dos materiais representados na sequência de talhe 2 ao apresentarem as suas extremidades distais arredondadas, bem destacadas por levantamentos marginais e semi-abruptos ao longo dos bordos adjacentes, permitindo a conservação no anverso, em posição central, da morfologia original do suporte utilizado (Fig. 8a)

Na sequência de talhe 4 agrupa-se um conjunto de 11 artefactos que no essencial replicam alguns dos processos de configuração associados às sequências de talhe anteriormente descritas, recombinando-os tendo em vista a definição de peças com características similares, isto é, com uma extremidade distal apontada, na maior parte das vezes adelgaçada e arredondada por retoque, que se opõe a uma base quase sempre espessa e cortical. A definição inicial destes artefactos segue a sequência de talhe 3, daí resultando também o predomínio de utensílios com uma extremidade distal criada por levantamentos invasores, que adelgaçam localmente esta zona da peça, determinando-se em simultâneo o arredondamento da extremidade por retoque (Fig. 6e). Por vezes este atributo não é confirmável devido à fractura do objecto (Fig. 8b). Dois dos artefactos inventariados correspondem, contudo, à definição de peças apontadas com uma morfologia claramente afilada, 

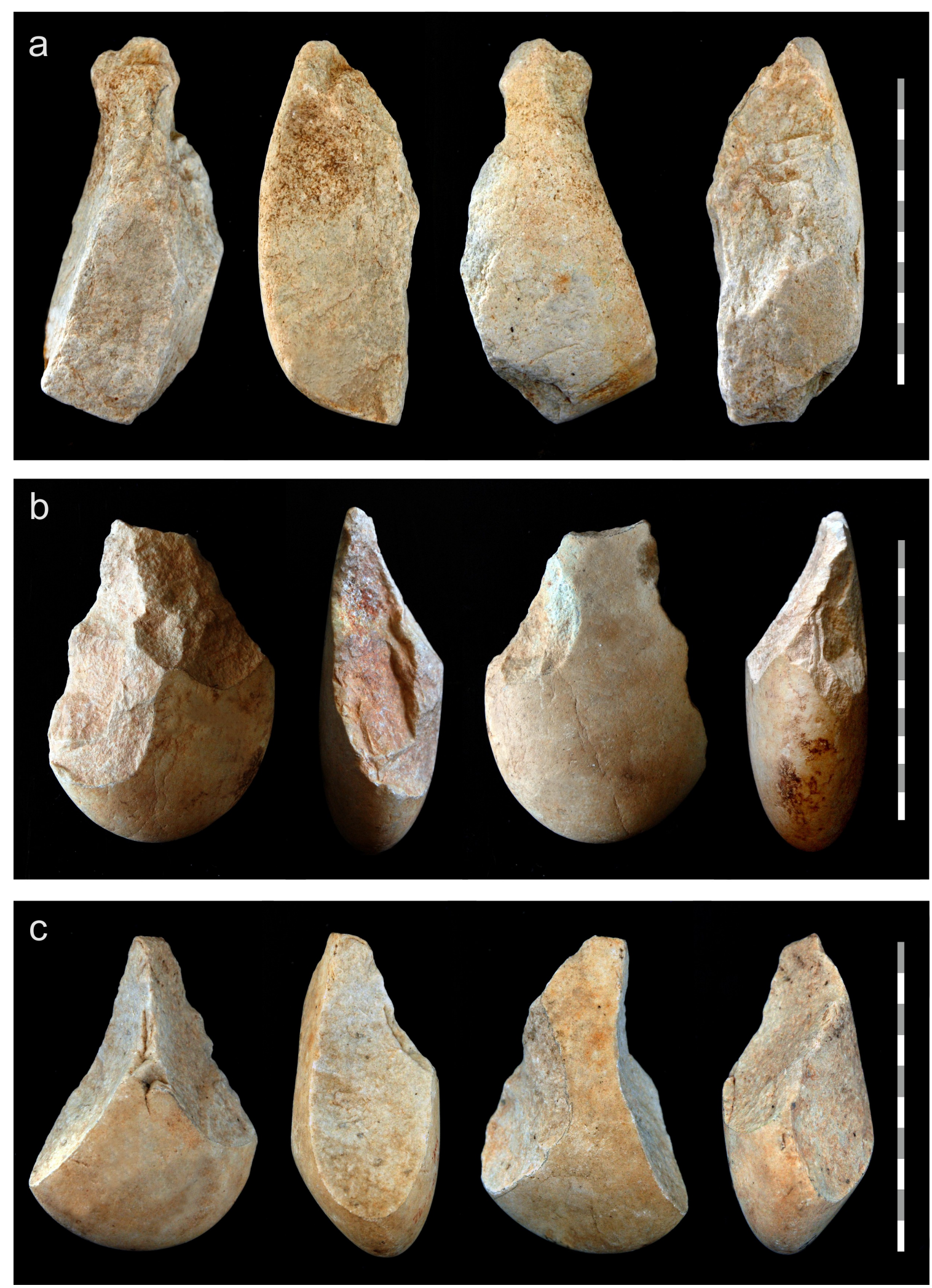

Fig. 8. Utensílios com configuração bifacial (II). a: Sequência de talhe 3; b e c: Sequência de talhe 4. Fig. 8. Bifacial shaped tools (II). a: Shaping sequence 3; b and c: Shaping sequence 4. 
associada a criação de bordos convergentes, através de levantamentos oblíquos ou semi-abruptos, marcadamente marginais (Fig. 8c). O que separa porém estas peças das suas congéneres unifaciais da sequência de talhe 3 é o facto de após se finalizar a configuração unifacial do anverso, se proceder ao talhe parcial do reverso num dos bordos, através da realização de um único e amplo levantamento ou, por vezes, criando um limitado número de negativos adjacentes, por vezes com amplitude invasora (Fig. 5). Recorre-se, deste modo, a um expediente utilizado tanto na sequência de talhe 1 como na 2 , já não para tirar partido da superfície assim criada como plano de percussão para desenvolver o talhe na face oposta, mas tão-só para reforçar o destaque da respectiva extremidade distal com o acentuar da concavidade do bordo bifacial daí resultante (Fig. 8b).

Embora podendo considerar-se um desenvolvimento das duas sequências de talhe imediatamente anteriores, a sequência de talhe 5 surge já associada a um processo de configuração de peças marcadamente bifaciais, através do desenvolvimento sequencial do talhe das suas duas faces. Na prática resulta na configuração inicial do anverso do utensílio por forma a esboçar desde logo uma morfologia apontada, recorrendo para o efeito à extracção de levantamentos com uma amplitude variável, nalguns casos limitados à parte distal da peça, onde incidem de forma tendencialmente mais invasora, por vezes desenvolvendo-se de maneira significativa pelos bordos adjacentes. Utilizando em seguida como plano de percussão os negativos resultantes desta primeira fase de produção da peça, inicia-se então o talhe do reverso, através do qual tanto se procura reforçar a definição da morfologia da extremidade distal, como também alargar, por vezes, o talhe a outras áreas do reverso, alterando-se mesmo, nalguns casos, a volumetria original do suporte (Fig. 5).

$\mathrm{O}$ posterior desenvolvimento de retoques de regularização dos bordos no anverso, observado numa ou noutra peça, sugeriu a individualização de uma versão mais elaborada desta sequência de talhe, identificada como $5 \mathrm{~b}$. No entanto, em qualquer uma das versões $-5 \mathrm{a}$ e $5 \mathrm{~b}$ - assiste-se ao desenvolvimento sequencial do talhe das duas faces (Fig. 5).

Em termos gerais pode dizer-se que as peças bifaciais obtidas pelo desenvolvimento da sequência de talhe 5 não se afastam muito, na definição dos seus atributos, do arquétipo geral dos artefactos produzidos através da aplicação das sequências de talhe mais expeditas que anteriormente se descreveram. Embora 10 das 21 peças inventariadas apresentem a sua extremidade distal fracturada (Fig. 9a), todas evidenciam morfologias apontadas que se contrapõem a bases espessas, resultantes da preservação da volumetria original dos suportes (Fig. 6f). Apenas em três situações em que o suporte corresponde a lascas de quartzito foi possível identificar a ocorrência de bases parcialmente cortantes, num ou noutro caso associadas à presença de talhe unifacial. Prevalecem também aqui as peças em que sobressai a presença de uma extremidade distal bem destacada, tendencialmente adelgaçada e arredondada por retoque (Fig. 9b), a par de outras que se distinguem pela morfologia afilada da respectiva extremidade distal, resultante geralmente da convergência de dois bordos definidos por levantamentos marginais e oblíquos, que se intersectam para formar um plano diédrico (Fig. 6f). Surge igualmente um número bem mais reduzido de artefactos cujo anverso é definido por levantamentos marcadamente periféricos, oblíquos ou mesmo semi-abruptos, que não se intersectam, permitindo a preservação de uma placa cortical central que se estende até á extremidade distal da peça (Fig. 9c).

Por último, foi ainda possível identificar uma outra sequência de talhe de configuração de peças estritamente bifaciais, baseada preferencialmente no desenvolvimento alternante do talhe das duas faces - sequência de talhe 6 (Fig. 5) - por vezes intercalado por pontuais operações de talhe bifacial sequencial de algumas zonas dos bordos ou mesmo da totalidade de um deles. Aparentemente trata-se de uma estratégia de talhe também ela expedita, que se vai adaptando em função dos resultados que vão sendo obtidos, constituindo uma opção claramente distinta da prosseguida nas sequências de talhe anteriormente descritas.

Daí a produção de um conjunto de artefactos marcadamente diferenciados, resultante, em geral, de uma alteração bem mais significativa da volumetria original dos suportes utilizados, o que também explica que em quase metade das peças desta sequência de talhe não tenha sido mesmo possível determinar a sua natureza. Entre os 29 artefactos inventariados coexistem e combinam-se distintas morfologias das respectivas extremidades distais e proximais, bem como peças com uma apurada e equilibrada configuração morfológica, a par de outras manifestamente mais irregulares e atípicas, mas onde todavia a definição pelo menos parcial da sua volumetria é expressivamente bifacial (Fig. 6g).

Uma análise conjunta das diferentes sequências de talhe acabadas de descrever permite considerar que no âmbito dos sistemas de produção de utensílios líticos talhados da jazida paleolítica do Cerro, a expressiva representação dos artefactos que em termos formais podemos associar aos bifaces, aos bifaces parciais, aos unifaces e aos esboços de bifaces está ligada à existência duas diferentes cadeias operatórias.

A primeira a considerar coincide com a própria sequência de talhe 6 , traduzindo-se na produção de uma gama variada de utensílios definidos por talhe bifacial, a partir de diferentes tipos de suportes. Em termos tecnológicos, a produção destas peças assenta no talhe alternante das duas faces, que determinam a volumetria bifacial em que se baseia a própria definição destes mesmos artefactos, não deixando todavia de se recorrer, quando necessário, 

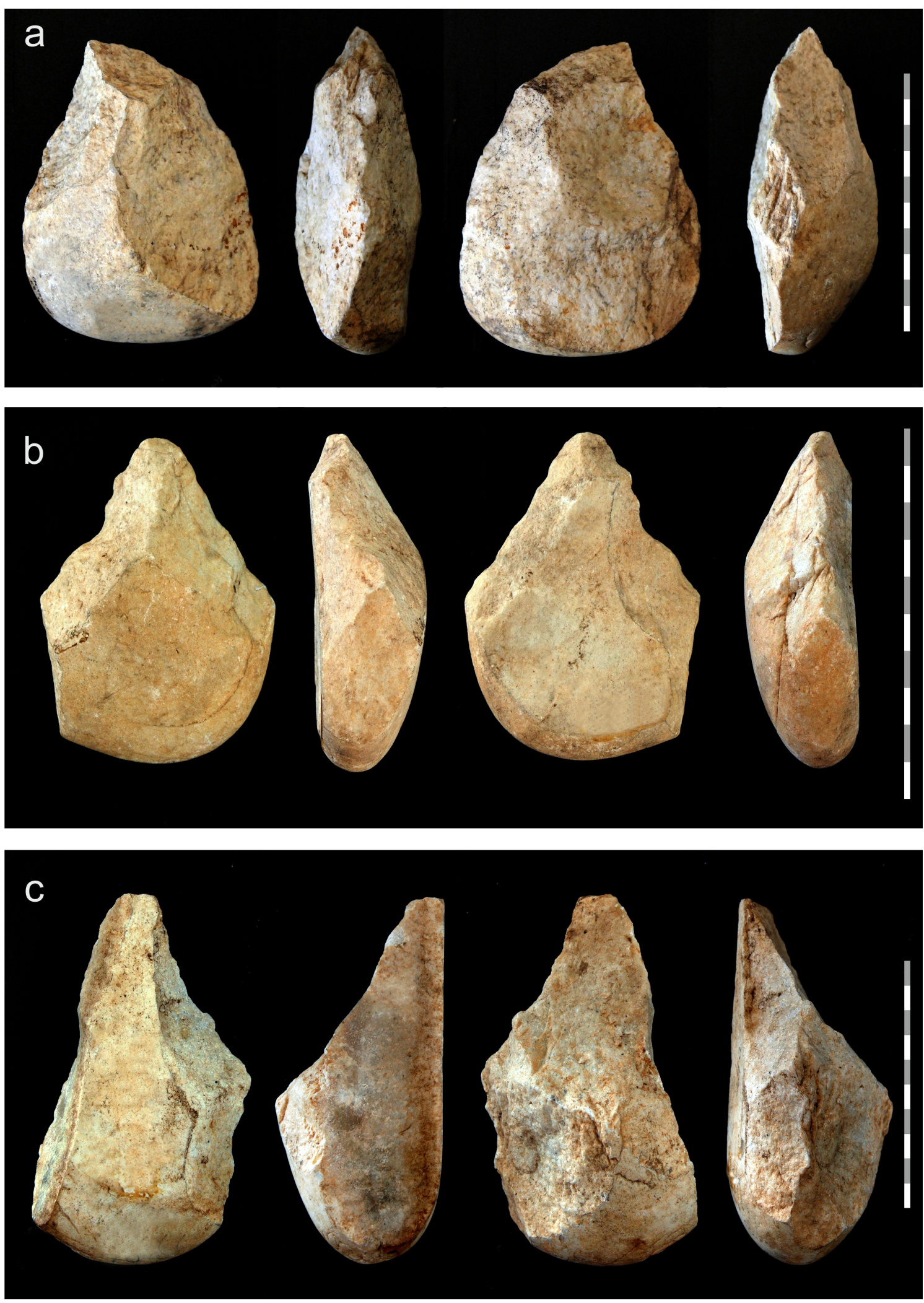

Fig. 9. Utensílios com configuração bifacial (III). a, b e c: Sequência de talhe 5 .

Fig. 9. Bifacial shaped tools (III). a, b and c: Shaping sequence 5. 
a estratégias diferenciadas mas complementares, como sucede com a aplicação pontual do talhe bifacial sequencial nalgumas zonas das peças onde tal se justificou. Os artefactos assim obtidos correspondem globalmente ao arquétipo dos bifaces acheulenses, incluindo-se entre eles toda a diversidade morfológica que a sua putativa multifuncionalidade permite comportar.

Já na segunda cadeia operatória, claramente maioritária e como tal considerada como principal, agrupam-se todas as restantes sequências de talhe identificadas, à excepção da "0", onde se integram alguns, poucos, artefactos cuja sumária configuração por talhe resultou do aproveitamento judicioso de suportes variados, mas com morfologias sugestivas. Duas das sequências de talhe (1 e 2) evidenciam um claro desenvolvimento independente, enquanto as três restantes ( 3,4 e 5), embora possam ser consideradas autonomamente, a elas se agregando mesmo um significativo número de peças, sugerem o desenvolvimento potencial de um processo linear de complexificação. Qualquer utensílio unifacial da sequência de talhe 3 pode corresponder a uma fase preparatória da subsequente sequência de talhe 4 , bastando para tal a extracção no reverso da peça de um ou mais levantamentos adjacentes cuja incidência num dos seus bordos permita destacar melhor a morfologia da extremidade distal. De igual forma, qualquer peça associável à sequência de talhe 4 pode transformar-se num artefacto bifacial definido por talhe mais amplo, de acordo com o agenciamento previsto na sequência de talhe 5 , enveredando para o efeito por qualquer das versões que a mesma inclui.

Este agrupamento numa mesma cadeia operatória das sequências de talhe referidas $(1,2,3,4$ e 5$)$ justifica-se na medida em que elas constituem, no seu conjunto, uma variedade de alternativas visando o mesmo fim. A opção por uma ou por qualquer outra delas, bem como o potencial desenvolvimento sequencial que as três últimas permitem mesmo delinear, resultou essencialmente da forma como se procurou pôr em prática a maneira mais adequada possível de concretizar o projecto pretendido: a obtenção de um artefacto de morfologia apontada, cuja extremidade distal se destaca da volumetria geral da peça, através de uma maior ou menor extensão e amplitude do talhe dos bordos adjacentes, conservando-se ao mesmo tempo, em posição proximal, uma expressiva zona espessa, frequentemente sem qualquer alteração do suporte original.

A maior espessura do suporte, por exemplo, poderá ter sido provavelmente determinante para justificar a opção pela sequência de talhe $2 \mathrm{em}$ detrimento da sequência de talhe 1 , obrigando a um mais amplo desbaste por talhe tendencialmente invasor de uma das faces da peça. De igual forma, a diferenciada e nem sempre regular morfologia dos suportes parece ter sido decisiva para a configuração da peça se quedar pela etapa correspondente à sequência de talhe 3 ou, em alternativa, ter obrigado a um processo mais complexo de transformação do suporte com recurso à sequência de talhe 4 ou mesmo à 5 .

Em todo caso, na situação em que se regista o desenvolvimento desta última sequência de talhe estamos perante uma realidade que de perto se aproxima do arquétipo das já atrás referidas peças bifaciais acheulenses, embora aqui a extensão e amplitude da sua bifacialidade se revele marcadamente mais diversificada e parcial. Isto não impede, porém, que não se reconheça, com o seu agrupamento na cadeia operatória onde coexistem as restantes sequências de talhe mencionadas, a existência de uma realidade tecnológica que vai muito para além da mera identificação formal de um significativo conjunto de esboços de bifaces, unifaces e bifaces parciais entre os materiais líticos talhados a partir de seixos rolados de quartzito, provenientes da jazida do Cerro.

Tanto a persistente conservação da morfologia original do suporte na zona proximal das peças, como a cuidada e destacada configuração da sua extremidade distal e a própria extensão e amplitude do talhe dos bordos adjacentes, permitem relevar atributos aparentemente indissociáveis das suas características funcionais.

Recorrendo ao conceito de unidade tecnofuncional desenvolvido por Eric Boëda para o estudo das peças bifaciais (BOËDA 2001) (Fig. 10), num contexto com contornos algo distintos, reconheça-se, não é possível deixar de individualizar entre os artefactos da cadeia operatória principal a presença de três distintas unidades tecno-funcionais. Tendo em conta que "le mode de fonctionnement comprend la mise en place de l'ensemble des caractères techniques opérationnels qui concernent tout aussi bien la partie transformative de l'outil que sa partie préhensive" (BOËDA 2001: 52), é sugestiva a associação da ausência de vestígios de talhe na zona basal das peças, com a consequente preservação local da morfologia original do suporte, à definição de uma unidade tecno-funcional de preensão (Fig. 10). Ela serviria não apenas para agarrar a peça, mas também para a manipular, conferindo a possibilidade de se lhe aplicar a energia indispensável à sua eficaz funcionalidade.

Mas não deixa também de ser significativo que a esta realidade incontornável, que se destaca pela ausência de qualquer vestígio de transformação do suporte original na região proximal, se contraponha, exactamente na extremidade oposta da peça, a cuidada definição de uma extremidade distal de morfologia variável. Ela corresponde claramente à definição de uma unidade tecno-funcional transformativa (BOËDA 2001), podendo a diversidade morfológica que apresenta sugerir a sua adequação ao eventual desenvolvimento de distintas funções (Fig. 10).

A operacionalidade de uma ponta criada pela intersecção de um plano diédrico, definido por talhe bilateral convergente, com o plano do reverso da peça, distingue-se naturalmente da associada a uma extremidade distal destacada premeditada- 


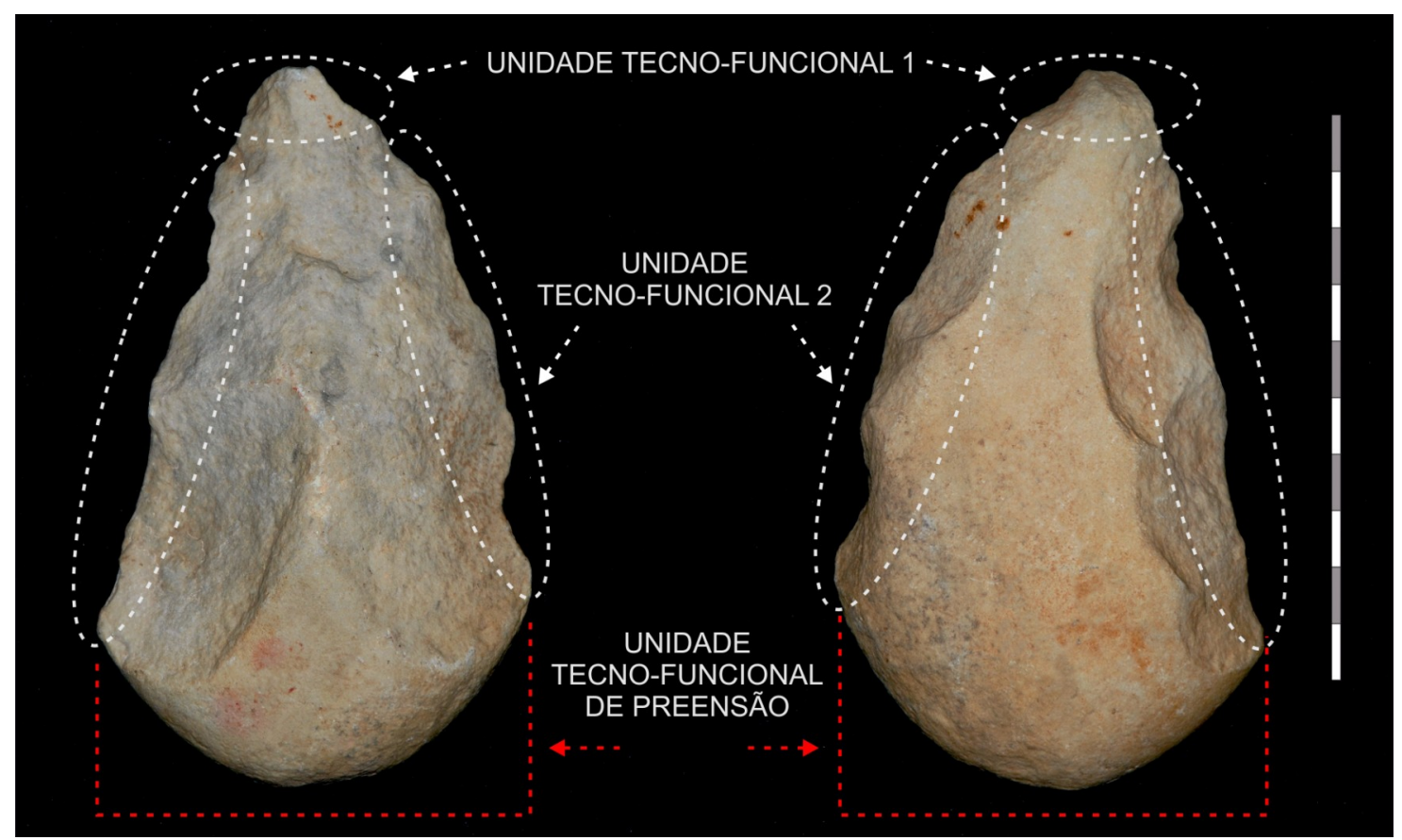

Fig. 10. Unidades técno-funcionais dos utensílios com configuração bifacial (seg. BOËDA 2001). A unidade técno-funcional 1 corresponde à extremidade distal do utensílio e a 2 às arestas laterais. Na base conserva-se a unidade tecno-funcional de preensão. Fig. 10. Techno-functional units of the bifacial shaped tools (acc. BOËDA 2001). Techno-functional unit 1 corresponds to the tip of the tool; techno-functional unit 2 corresponds to the edges. In the proximal portion of the tool the prehension techno-functional unit is preserved.

mente pela concavidade dos bordos adjacentes da silhueta do artefacto, cuja ponta se apresenta arredondada por retoque. Nalguns casos verifica-se o adelgaçamento de algumas destas extremidades distais arredondadas, igualmente por retoque, ou a sua definição pode ainda integrar a preservação do córtex original em posição central.

Mas se nalgumas das situações consideradas a centralidade da definição da extremidade distal associa à respectiva configuração o talhe parcial dos bordos adjacentes, o que aparentemente delimita a sua funcionalidade, noutras o talhe bifacial, parcialmente bifacial ou mesmo unifacial desses bordos laterais assume um protagonismo que permite relacioná-los com a individualização de uma segunda unidade tecno-funcional materializada nos gumes laterais (Fig. 10). De facto, mesmo quando a morfologia original do suporte determinou a extracção de levantamentos marcadamente marginais e com uma inclinação oblíqua ou semiabrupta, o gume assim obtido nem por isso deixou de constituir uma zona potencialmente activa nas peças em apreço, independentemente da sua maior ou menor adequação ao desempenho de determinadas tarefas.

\section{CONCLUSÕES}

Pode-se pois concluir que, no seu conjunto, as peças bifaciais, parcialmente bifaciais e unifaciais integradas na cadeia operatória principal testemunham a produção de artefactos associáveis ao desenvolvimento de utensílios apontados de acordo com estereótipos diversificados mas bem precisos. Para a sua configuração recorre-se, porém, a distintas sequências de talhe sem uma ligação perceptível com as diferentes morfologias que lhes estão associadas, mas aparentemente condicionadas pela morfologia e pela maior ou menor regularidade dos suportes utilizados.

$\mathrm{O}$ resultado obtido deixa transparecer a pertinente adequação das opções técnicas realizadas, revelando na maior parte dos casos o carácter expedito de muitos dos processos utilizados na configuração de boa parte das peças estudadas, coexistindo tal realidade com outras aparentemente mais complexas, mas apenas associadas a processos operatórios mais alongados (RoCHE \& TEXIER 1991), sem que tal nem sempre se traduza numa diferenciação funcional explícita.

Esta análise preliminar das peças bifaciais da jazida paleolítica do Cerro permite chamar a atenção para a importância de alargar o estudo tecnológico das indústrias paleolíticas baseadas na quase exclusiva utilização do quartzito como matéria-prima, sob a forma de seixos rolados, às múltiplas situações e facetas com que tal realidade arqueológica surge representada. Via, aliás, que investigações recentes têm vindo a reforçar (CURA 2013), nela integrando a realização de remontagens ou o recurso à experimentação e à traceologia. Mas se a adversidade dos contextos a que muitas vezes estas indústrias líticas surgem associadas não permite amiúde o pleno desenvolvimento de algumas destas abordagens, nem por isso o seu estudo tecnológico mais aligeirado deixa de abrir 
portas para novas interpretações, tornando possível ultrapassar os espartilhos impostos pela anterior prevalência do paradigma morfo-tipológico em que se estruturava a percepção destas materialidades.

\section{AGRADECIMENTOS}

Os autores agradecem ao Prof. Doutor José Meireles Batista, da Universidade do Minho, a leitura atenta deste trabalho e os seus contributos no sentido de o melhorar. Agradecem igualmente aos revisores científicos as apreciações críticas e as diversas sugestões.

\section{BIBLIOGRAFIA}

ARAÚJO M.A. 1984. A Formação "Areno-pelítica de cobertura". Alguns resultados dum estudo preliminar. Biblos, vol. LX: 71-89.

ARAÚJo M.A. 1991. Evolução geomorfológica da plataforma litoral da região do Porto. Dissertação de Doutoramento, Universidade do Porto.

ARAÚJO M.A 1995. Os fácies dos depósitos würmianos e holocénicos e as variações climáticas correlativas na plataforma litoral da região do Porto. Actas VI Colóquio Ibérico de Geografia, vol. II. Porto: Universidade do Porto: 783-793.

ARAÚJO M.A. 1997. A plataforma litoral da região do Porto: Dados adquiridos e perplexidades. Estudos do Quaternário 1, Lisboa: APEQ: 3-12.

ARAúJo M.A. 2008. Depósitos do Pleistocénico Superior e do Holocénico na plataforma litoral da região do Porto: a morfologia das plataformas de erosão marinha e a tectónica recente. Estudos do Quaternário 5: 17-30.

ARaúJo M.A.; Gomes A.; Chamine H.I.; FonseCa P.E.; GAMA P.L.C.; PINTO J.A. 2003. Geomorfologia e geologia regional do sector de Porto-Espinho (W de Portugal): implicações morfoestruturais na cobertura sedimentar cenozóica. Cadernos do Laboratorio Xeológico de Laxe 28: 79-105.

BOËDA, E. 2001. Determination des unités techno-fonctionelles de pièces bifaciales de la couche acheuléenne C'3 Base du site de Barbas I. In «Actes de la table-ronde internationale organisée à Caen (Basse-Normandie - France)». Liège: ERAUL 98: 51-75.

CostA, J.C. \& TEIXEIRA, C. 1957. Notícia explicativa da Carta Geológica de Portugal, Folha 9-C (Porto), escala 1/50000. Lisboa: Serviços Geológicos de Portugal.
CUnHA, P.P.; Martins, A.A.; HuOT, S.; MurRay, A.; RAPOSO L 2008. Dating the Tejo river lower terraces in the Ródão area (Portugal) to assess the role of tectonics and uplift. Geomorphology, doi:10.1016/j.geomorph.2007.05.019

CURA, S.R.M. 2013. Tecnologia litica e comportamento humano no Pleistocénico Médio do Alto Ribatejo: estudo da indústria lítica da Ribeira da Ponte da Pedra. 2 Vols. Vila Real (Dissertação de Doutoramento apresentada à Universidade de Trás-os-Montes e Alto Douro).

Martins, A.A.; CunHA, P.P.; HuOT, S.; MurRay, A.S.; BUYLAERT, J.P. 2009. Geomorphological correlation of the tectonically displaced Tejo River terraces (Gavião - Chamusca area, central Portugal) supported by luminescence dating. Quaternary International 199: 75-91. doi:10.1016/j.quaint.2009.01.009

MonTEIRO-RodrigueS S. \& GonZÁLEZ A. 2010. A estação paleolítica da Praia da Aguda (Arcozelo, Vila Nova de Gaia). Notícia preliminar. Estudos do Quaternário 6: 23-36.

Monteiro-Rodrigues S. \& CUNHA-Ribeiro J.P. 1991. A Estação Paleolítica do Cerro - Madalena, Vila Nova de Gaia. Revista da Faculdade de Letras - História 8, II série: 411-428.

MONTEIRO-Rodrigues S. \& SANCHES, M.J. 2006. Os primeiros recolectores e caçadores (Paleolítico). In C.A. Brochado de Almeida (Coord.), História do Douro e do Vinho do Porto. História Antiga da Região Duriense. Vol. I, Porto: GEHVID/ Ed. Afrontamento: 30-77.

Ribeiro, H.; Pinto de Jesus, A.; Mosquera, D.F.; ABreu, I.; Vidal Romani, J.R.; NorOnHA, F. 2010. Estudo de um terraço de Lavadores. Contribuição para a dedução das condições paleoclimáticas no Plistocénico médio. e-Terra. Revista Electrónica de Ciências da Terra, Vol. 21/1: 1-4. http://e-terra.geopor.pt

Roche, H. \& TEXIER, P.-J. 1991. La notion de complexité dans un ensemble lithique. Application aux séries acheuléennes d'Isenya (Kenya). In «25 ans d'Études Technologiques en Préhistoire. XIe Rencontres Internationales d'Archéologie et d'Histoire d'Antibes». Juan-les -Pins: Éditions APDCA: 99-108

TeIXeIrA, C. \& PERdigão, J. 1962. Notícia explicativa da Carta Geológica de Portugal, Folha 13-A (Espinho), escala 1/50000. Lisboa: Serviços Geológicos de Portugal.

ZBYSZEWSKI, G. 1943. La classification du Paléolithique ancien et la chronologie du Quaternaire du Portugal en 1942. Boletim da Sociedade Geológica de Portugal, vol. II, 2/3: 1-113. 